\title{
The Death Penalty Between International Guarantees and Moroccan Law
}

\author{
Fatima Ezzohra El hajraoui \\ PHD Student, Hunan university \\ Ed.daran Driss \\ Assistant Professor, Taibah University
}

\begin{abstract}
For as long as the human right to life was the main goal of an international community, a number of global conventions and regional and international resolutions were aimed at reducing the death penalty. However, this does not mean that the death penalty and retribution in the Arab countries (Islamic Countries) were abolished; they were and still are a black point that stands in front of this right. In many parts of the world, the death penalty is now understood to be a human rights violation. This understanding has led to progress in the abolition of the death penalty in almost all the countries. Countries which have not abolished the death penalty can execution it only for the most serious crimes and issued pursuant to a final judgment of a competent court, with the possibility of Pardon or commutation of sentence. There are limitations to practice the death penalty, like application of the death penalty for persons who not reach eighteen years of age. Examining the death penalty from a human rights perspective not only highlights the impact of denying the most basic right to all other rights but also demonstrates why the only "solution" to the death penalty is to permanently end its use. In this paper, we discuss the most important points in the death penalty, which is the evolution of the death penalty, considering international efforts to abolish capital punishment. Then, the safeguards guaranteeing protection of the rights of those facing the death penalty give us illustrations of some countries. Finally, we discuss the death penalty in the Moroccan law as one of the countries that did not recognize in their national laws to cancel the punishment, and did not work on it since 1993. This is without forgetting to give some suggestions on this subject.
\end{abstract}

\section{INTRODUCTION}

The most important human right, which is protected and codified by international conventions, is the right to life. This right pushes the international community to issue treaties, protocols, declarations, and recommendations aimed at prohibiting the withdrawal of the human right to life and execute the death penalty under the law.

In the last few years, the death penalty was criticized by many scholars in different areas because it is very harsh, definitive, and irreversible after execution even if we knew that this person was innocent.

The death penalty does not achieve the pursued goals of the state especially when the criminals escape with impunity while the most important measures are to reform and rehabilitate the criminal.

But the death penalty supporters see that it provides and establishes the maximum level of scare in the society and pushes the people to refrain from the crimes which are punishable by death. This is what we can call the "deterrence function of the death penalty ", where the death 
penalty has a high impact on achieving the goals of society in the fight against the dangerous crimes which threaten the stability of the society.

No doubt that the human life is the highest right which gets special interest from the individual themselves. The death penalty makes persons take suitable actions and avoid committing crimes.

More than 54 countries, led by China, Iran, the United States, and Iraq continue to execute the death penalty, but the Authorized figures do not reflect the reality because of the lack of transparency related to the death penalty prevailing in some countries (China, Iran, Saudi Arabia, Japan ...).

The main reasons of death sentences in the world are: Murder, Corruption, Pimping, Robbery, Adultery, Homosexuality, Drug trafficking, and Economic crimes (tax evasion, abuse of confidence, etc). The death penalty is executed in so many ways like Decapitation (Saudi Arabia), Electrocution (USA), Hanging (Egypt, Iran, Iraq, Jordan, Pakistan, Singapore), Lethal injection (USA, China, Guatemala, Thailand), Stoning (Afghanistan, Iran).

This paper is divided into three chapters. The first chapter takes us through the Development of International Human Right about Death Penalty. The second chapter discusses Safeguards guaranteeing protection of the rights of those facing the death penalty. The third one discusses the death Penalty in the Moroccan law as an example.

\section{CHAPTER 1: DEVELOPMENTS OF THE DEATH PENALTY IN THE INTERNATIONAL HUMAN RIGHTS LAW}

The international human rights law has been adopted recently. Like other human rights, the right to life has begun to be considered as a matter falling within the remit of this law since December 10, 1948, the date of the adoption of the Universal Declaration of Human Rights (UDHR). The UDHR put an end to a long period in which the notion of "reserved area" was applied without hesitation to human rights-related affairs by deeming them as falling within the domestic jurisdiction of a State.

The preparatory proceedings for the UDHR show that the abolition was not on the agenda, despite the fact that the Soviet bloc had advocated the abolition of the capital punishment in peace time, as was the case with the USSR who had officially abolished it in 1947.

The Soviet bloc proposed an amendment to Article 3 of the UDHR on the right to life. It was rejected by the UN Commission on Human Rights,by 21 votes against 9 and 18 abstentions. It is worth mentioning that this vote should not be considered as for or against capital punishment.

In 1950 General Assembly called for all United Nations Member States to observe UDHR adoption day as the International Day of Human Rights, and if the UDHR has included thirtieth legal text, what concerns us in these texts are Article 3 and 4 (a right to life and the right to liberty and the right to security of persons..... and liberation from slavery, servitude and the prevention of torture or degrading treatment or cruel), but this kind of rights lead us to abolishing the death penalty.

In the same year, the European Convention on Human Rights this question would be dealt with explicitly for the first time. Article 2 of the Convention enshrines what appears to be an exception: "everyone's right to life shall be protected by law. No one shall be deprived of his life 
intentionally save in the execution of a sentence of a court following his conviction of a crime for which this penalty is provided by law". This dual requirement of "legality" of the sentence pronounced by a "court" in the Convention means, according to case law, an independent and impartial tribunal guaranteeing the rights of defense. However, we can say that these procedural safeguards can only reinforce the "legality" of the death penalty and its legitimacy under the Convention.

On 19th December 1966 , the General Assembly resolution 2200 A has Adopted three international instruments of human rights and human dimensions economic, political and cultural rights, including the International Covenant on Civil and Political Rights and the International Covenant on Economic, Social and Cultural Rights, and the Protocols hereto have confirmed the basic principles of covenants mentioned. International commitment stated in the versions, in particular Article 6 included (shall be protected by law. No one shall be arbitrarily deprived of his life), has acknowledged this right in the second Protocol to the Covenant on Civil and political rights, adopted by the General Assembly of the United Nations in 12/15/1989 but it entered into force on July 11, 1991 , and in accordance with the provisions of Article 8, which aims to abolish the death penalty, and which was approved by forty countries of the world (i.e. Abolish the death penalty in their national laws) .

In the international scale, the universal declaration and convention and international instruments mentioned above confirmed the right to life. It is binding on the parties signatory in accordance with Article 110/4 of the Charter and Article 26 of the Vienna Conventions of 1969. Either on a regional scale, the EU abolished the death penalty and replaced it with life imprisonment for life, and European tribunal of human rights admitted that it needed to consider the fundamental right of the individual and his physical health when the death penalty is on the table, attended torture or inhumane treatment in the extradition proceedings and the possibility of refusing extradition when there are dangers of violating this right.

In 1986, 46 countries had abolished the death penalty for ordinary crimes.

Sixteen years later, the number of countries in the same category had almost doubled to 89. Moreover, another 22 countries had stopped using the death penalty in practice, bringing the total of non-death penalty countries to 111, far more than the 84 countries which retain an active death penalty.

Roger Hood, in his book about world developments in the death penalty, noted that: "The annual average rate at which countries have abolished the death penalty has increased from 1.5 (1965-1988) to 4 per Year (1989-1995), or nearly three times as many." International law experts, William Schabas, noted that fifty years ago this topic did not even exist because there were virtually no abolitionist countries.

The countries have abolished the death penalty in increasing numbers vary. For some nations, it was a broader understanding of human rights. Spain abandoned the last vestiges of its death penalty in 1995, stating that: "the death penalty has no place in the general penal system of advanced, civilized societies ....

However, for an increasing number of countries the death penalty is a critical human rights issue. In 1997, the U.N. High Commission for Human Rights approved a solution stating that the 
"abolition of the death penalty contributes to the enhancement of human dignity and to the progressive development of human rights."

Until now there are so many efforts to abolish the death penalty from the international community. What more degrading or afflictive punishment can be imagined than to deprive a person of his life?

\section{CHAPTER 2: SAFEGUARDS GUARANTEEING PROTECTION OF THE RIGHTS OF THOSE FACING THE DEATH PENALTY}

\section{A. The Economic and Social Council of the United Nations}

The Economic and Social Council of the United Nations in its resolution No. 50/1984 fixed 25 May 1984 has adopted many of the safeguards guaranteeing protection of the rights of individuals facing the death penalty, and this confirms diligence and care accorded by the United Nations of the right to life as an inherent right, and has taken into account the decision of many categories, groups and individuals that may face the occurrence of the death penalty against them.

1. In countries which have not abolished the death penalty, capital punishment may be imposed only for the most serious crimes, it being understood that their scope should not go beyond intentional crimes with lethal or other extremely grave consequences.

2. Capital punishment may be imposed only for a crime for which the death penalty is prescribed by law at the time of its commission, it being understood that if, subsequent to the commission of the crime, provision is made by law for the imposition of a lighter penalty, the offender shall benefit thereby.

3. Persons below 18 years of age at the time of the commission of the crime shall not be sentenced to death, nor shall the death sentence be carried out on pregnant women, or on new mothers, or on persons who have become insane.

4. Capital punishment may be imposed only when the guilt of the person charged is based upon clear and convincing evidence leaving no room for an alternative explanation of the facts.

5. Capital punishment may only be carried out pursuant to a final judgment rendered by a competent court after legal process which gives all possible safeguards to ensure a fair trial, at least equal to those contained in article 14 of the International Covenant on Civil and Political Rights, including the right of anyone suspected of or charged with a crime for which capital punishment may be imposed to adequate legal assistance at all stages of the proceedings.

6. Anyone sentenced to death shall have the right to appeal to a court of higher jurisdiction, and steps should be taken to ensure that such appeals shall become mandatory.

7. Anyone sentenced to death shall have the right to seek pardon, or commutation of sentence; pardon or commutation of sentence may be granted in all cases of capital punishment.

8. Capital punishment shall not be carried out pending any appeal or other recourse procedure or other proceeding relating to pardon or commutation of the sentence.

9. Where capital punishment occurs, it shall be carried out so as to inflict the minimum possible suffering.

\section{B. The International Covenant on Civil and Political Rights}

Also The International Covenant on Civil and Political Rights confirmed Almost the same standards in Article 6 so that: 
1. Every human being has the inherent right to life. This right shall be protected by law. No one shall be arbitrarily deprived of his life.

2. In countries which have not abolished the death penalty, sentence of death may be imposed only for the most serious crimes in accordance with the law in force at the time of the commission of the crime and not contrary to the provisions of the present Covenant and to the Convention on the Prevention and Punishment of the Crime of Genocide. This penalty can only be carried out pursuant to a final judgment rendered by a competent court.

3. When deprivation of life constitutes the crime of genocide, it is understood that nothing in this article shall authorize any State Party to the present Covenant to derogate in any way from any obligation assumed under the provisions of the Convention on the Prevention and Punishment of the Crime of Genocide.

4. Anyone sentenced to death shall have the right to seek pardon or commutation of the sentence. Amnesty, pardon or commutation of the sentence of death may be granted in all cases.

5. Sentence of death shall not be imposed for crimes committed by persons below eighteen years of age and shall not be carried out on pregnant women.

Nothing in this article shall be invoked to delay or to prevent the abolition of capital punishment by any State Party to the present Covenant. Article 7 states that no one shall be subjected to torture or to cruel, inhuman or degrading treatment or punishment. In particular, no one shall be subjected without his free consent to medical or scientific experimentation.

See the general comment of the human rights committee on Article 6 of the Covenant, mainly paragraphs 6 and 7 which state that: "While it follows from article 6 (2) to (6) that States parties are not obliged to abolish the death penalty totally they are obliged to limit its use and, in particular, to abolish it for other than the "most serious crimes". Accordingly, they ought to consider reviewing their criminal laws in this light and, in any event, are obliged to restrict the application of the death penalty to the "most serious crimes". The article also refers generally to abolition in terms which strongly suggest (paras. 2 (2) and (6)) that abolition is desirable. The Committee concludes that all measures of abolition should be considered as progress in the enjoyment of the right to life within the meaning of article 40, and should as such be reported to the Committee. The Committee notes that a number of States have already abolished the death penalty or suspended its application. Nevertheless, States' reports show that progress made towards abolishing or limiting the application of the death penalty is quite inadequate. "The Committee is of the opinion that the expression "most serious crimes" must be read restrictively to mean that the death penalty should be a quite exceptional measure. It also follows from the express terms of article 6 that it can only be imposed in accordance with the law in force at the time of the commission of the crime and not contrary to the Covenant. The procedural guarantees therein prescribed must be observed, including the right to a fair hearing by an independent tribunal, the presumption of innocence, the minimum guarantees for the defense, and the right to review by a higher tribunal. These rights are applicable in addition to the particular right to seek pardon or commutation of the sentence.

\section{The most important guarantees of the death penalty, and to what extent they are applied in some countries}

As we saw in the Economic and Social Council of the United Nations, and The International Covenant on Civil and Political Rights, there are three standards to protect the person convict to death: 


\section{Objective standard}

The capital punishment may be imposed only for the most serious crimes in the Report of the Secretary-General defined as intentional crimes with lethal or other extremely grave consequence. The application of this safeguard in recent years has focused on the use of the death penalty for crimes that are not intentional and that do not have lethal or other extremely grave consequences. In particular, imposing the death penalty for drug-related offences is in violation of article 6 , paragraph 2 , and the safeguards guaranteeing protection of the rights of those facing the death penalty. Harm Reduction International reported that there are currently 32 States or territories that prescribe the death penalty for drug-related offences.

This penalty can only be carried out pursuant to a final judgment rendered by a competent court. In this statement we can mention two points, the first is national court, not international court like International criminal court, even if its jurisdiction is about the most serious crimes, such as war crimes.

The second is that we can find most countries, such as China, Morocco, and Egypt, which have not abolished the death penalty use it in special crimes with strict limits.

China maintains capital punishment with certain restrictions on its use among 57 countries actively practicing it and 21 carrying out executions. China not only maintains the death penalty as chief executioner but also takes the responsibility of markedly reducing the number of executions in the world, e.g. precipitously from 12,000 executed prisoners to a quarter of them in one decade. This brighter trend results from the implementation of new policies, of which the death penalty policy is 'to kill less and cautiously', namely, 'those who do not have to be killed should not be sentenced to death', and the criminal policy is 'balancing leniency and severity'. The Chinese policies seem to essentially adopt strict limits on the use of the death penalty.

The same as in Egypt, the second paragraph in Article 381 of the Criminal Procedure Code stipulates that "the criminal court may issue a death sentence only by unanimous consent of its members and should take the view of the Mufti of the Republic before the issuance of the sentence." Accordingly, the legislator stipulated the unanimity when sentencing to death as a procedure and a prerequisite condition for the validity of the sentence, unlike the general rule in other sentences - but that was for the magnitude of the punishment in the death penalty, and in order to surround it by procedural guarantees to be very sure that the sentence is applied in cases in conformity with the law."

The aforementioned provision and the reported explanatory note to the law show that if the legislator requires the consensus on death penalty judgment as a regulatory procedure to render and a prerequisite for validity - an exception from the general rule in terms of rendering the judgment by majority -that is recognition of the gravity of the death penalty. The Legislator has surrounded the death penalty with procedural guarantees to ensure the rendering of death penalty in restricted cases which is certainly in conformity with the law.

The Court of Cassation also ruled that "Whereas Article 381 of the Procedures Code require the criminal court to take the opinion of the Mufti before the judgment to death, but there is no provision in the law requires the court to show Mufti opinion or to disproof it"

The Court of Cassation has pointed out the reason of requesting the legislator the Mufti's opinion before the death sentence saying: "the legislator intended that the judge should be 
aware whether the rules of Islamic law allow the execution in this case or not, and not for knowing the Mufti's opinion in adapting act ascribed to the offender and give him the legal description.

\section{Personal standard}

Persons below 18 years of age at the time of the commission of the crime shall not be sentenced to death, that's stipulated in International Human Rights Treaties and Convention on the Rights of the Child (article 37(a)), African Charter on the Rights and Welfare of the Child (article 17), and the American Convention on Human Rights (article 4(5)). For that the prohibition of the imposition of the death penalty on persons below eighteen years, has become at present time part of customary international law, and therefore creates an international obligation upon every state regarding the necessity to be taken into account in its laws, even if this state is not a party to the conventions on human rights .

This view is supported in the practical application of the Inter-American Commission on Human Rights in its resolution issued in communication No. 9647 on 27.04.1987, as the Commission recorded a violation of this restriction on the USA, after the courts of the states issued death sentence for two persons committed a crime and they were less than eighteen years. The commission based on articles 1 and 2 of the American Declaration of Human Rights, because the USA did not sign the American Convention on Human rights.

But indeed until now there are so many violations in some countries, such as Saudi Arabia, Iraq, Iran, and China.

The Economic and Social Council of the United Nations continues by stating that: "nor shall the death sentence be carried out on pregnant women, or on new mothers". In this case we need to be sure that we judge two persons; the mother and her child, either her or her born or not.

Here we must mention the first case in the world, it was in the period of Prophet Muhammad, after the women asked the Prophet to execute Stoning because she was caught in adultery and she was a chaste women. The Prophet delayed the sentence until two years after her baby was born.

States that prohibit the execution of pregnant women fall into categories: those which delay execution until after the woman has given birth, such as Morocco, Egypt, Bahrain, Thailand and the Central African Republic, and those which commute the death sentence into a term of imprisonment for life or less, such as Burkina Faso, Chad, Iran, Japan, Lebanon and South Korea

Other 23 countries which prohibit the execution of pregnant women were unable to determine whether delay or commutation was the law and/or practice. These countries include China, Cuba, Equatorial Guinea, Indonesia, Jamaica, Jordan, Mongolia, North Korea, Sierra Leone, South Sudan, Sudan, Suriname, Tanzania, the United States, Vietnam, and Zimbabwe.

Finally, 6 countries (Bangladesh, Eritrea, Ethiopia, Iraq, Myanmar, and Pakistan) have adopted an intermediate position where courts are empowered to exercise discretion in deciding whether to commute a pregnant woman's death sentence to life imprisonment after her delivery. 
For persons who have become insane, in accordance with Economic and Social Council resolution 1984/64, paragraph 1 (d), states should eliminate the death penalty "for persons suffering from mental retardation or extremely limited mental competence, whether at the stage of sentence or execution". This was reiterated by the Commission on Human Rights through resolution 2005/59.

No one shall be subjected to torture or to cruel, inhuman or degrading treatment or punishment. In particular, no one shall be subjected without his free consent to medical or scientific experimentation.

\section{Formal standard}

The death penalty may be carried out only pursuant to a final judgment rendered by a competent court after a process which gives all possible fair trial safeguards. The United Nations High Commissioner for Human Rights has expressed concerns with regard to the lack of a fair trial in death penalty cases in a number of States. For instance, in January 2012, the High Commissioner expressed her concerns at reports that 34 individuals, including two women, were executed in Iraq on 19 January following their conviction for various crimes. She expressed particular concern regarding "the lack of transparency in court proceedings, major concerns about due process and fairness of trials, and the very wide range of offences for which the death penalty can be imposed in Iraq"

Must make sure that the person and the evidence before the verdict, and this sentencing is the doomed decision determines the fate either to be with the neighborhoods or from the dead, for all of this imposing legislator must make sure that the evidence are true, leaving no room for an alternative explanation of the facts, and give the person the right to appeal to the Court of higher jurisdiction to reconsider the case. The Economic and Social Council of the United Nations stipulated that this step should be taken to ensure that such appeals shall become mandatory. In my opinion, I suggest to add some special court of serious crimes with Jurors in the law and familiar enough with the knowledge of criminality and law.

The international human rights treaties state that a person sentenced to death shall have the right to seek pardon or commutation of sentence. Amnesty International recorded pardons or commutations of death sentences in 33 States. This practice could be seen as a sign that a growing number of States accept that in some cases death sentences or executions are inappropriate for the crimes allegedly committed, or the legal process that led to the conviction is not consistent with international standards, and that, by avoiding executions, they wish to undertake steps to protect the right to life in line with national law and their obligations under international law.

Pardon or commutation of sentence may be granted in all cases of the death penalty, pardon of discharges the individual designated from all or some special penal consequence of his crime. It may be full or partial, absolute or conditional.

This function is performed by the highest authority in the country. For example, in Morocco, it is performed by the king of the country in all religious and national holidays, and for the benefit of all the people, regardless of the punishment, either imprisonment or capital punishment, provided that they had easing circumstances during the occurrence of the crime. On the 50th anniversary of Morocco's independence, he commuted 25 death sentences. In 2008, at his daughter's birth, he commuted 14 death sentences. In July 2009, on the tenth anniversary of his coronation, he commuted 32 death sentences. 
But in Egypt the article no. 470 of Criminal Procedures Code states that "when the judgment is being final, the lawsuit papers shall be immediately presented to The President of the Republic by the Minister of Justice ". According to the same article, second paragraph, the death penalty shall be executed within 14 days unless an order of amnesty or commutation has been issued. The wisdom behind that procedure is to give the person sentenced to death a last chance since the penalty is grave and to give the President of the Republic the opportunity to use his right of amnesty or of commutating the sentence.

The sentenced shall be placed in prison based upon an order issued by public prosecutor on a form prescribed by Minister of Justice (article no. 471 CCP). If religion of the sentenced imposes upon him the recognition or other religious rituals before death, necessary facilities shall take place to enable a clergy to meet him. Sentenced relatives shall meet him on the day of the execution of the judgment upon a condition of being the meeting away from the place of execution (Article 472 CCP).

\section{CHAPTER 3: DEATH PENALTY IN THE MOROCCAN LAW}

\section{A. The Moroccan legislator deals with the issue}

In its penal law, the Moroccan legislator deems the death penalty as principal. Moreover, it places it atop all sanctions. Despite this classification, and unless there is a contrary legal text, the Moroccan legislator gives the tribunal the jurisdiction over making the accused enjoy mitigating circumstances and applying life sentence or twenty to thirty years in prison, in the case whereby the death penalty is proved severe compared to the acts perpetrated by the accused or to the degree of his/her criminality.

The Moroccan legislator provides also for legal alternatives that help the tribunal to replace or commute the death penalty, as the case may be. The death penalty may be commuted to a sentence of 10 years to 15 years in prison in the cases of crimes perpetrated by juvenile offenders.

In parallel, in order to enhance some procedural safeguards concomitant of death penalty sentence, investigation is made compulsory in crimes where this penalty is applied.

\section{B. Criminal acts punished by the death penalty}

- The attack on the King, according to Article 163

- The attack on the life of the Crown Prince, according to Article 165

- The attack on the life of a royal family members, according to Article 167

- Be punished for a crime of treason, every Moroccan committed, in time of peace or war, one of the acts set forth in Article 181

- Be punished for a crime of treason, every Moroccan committed in time of war, one of the acts set forth in Article 182.

- Felony espionage, every foreigner committed one of the acts described in article 181, paragraph 2, 3, 4 and 5 and article 282.

- The felony touches the safety of a foreign state: every Moroccan or foreigner who damaged the unity of the Moroccan territory, at the time of war, according to Article 190.

- The crimes affecting the integrity of the internal state, who has committed an assault designed to either provoke a civil war by arming a group of people or push them into 
armament against another team, or sabotage and killings and looting the area or more, according to Article 201

- Crimes affecting the integrity of the internal state, according to Article 202, 203

- Crimes committed by employees against public order, according to Article 235

- Some terrorist acts, if resulted to the death of one or more persons.

- Insulting a public official, and assault him, according to Article 267

- Crimes against persons, according to Articles: 392, 393, 396, 398, 399, 410,438.

- Crimes of Vandalism and Destruction: Articles 580, 581, 583, 586 and 587 if the result is death one person or more. And Articles 590 and 591.

Finally, there is a set of crimes stipulated by the military justice law for military crimes.

\section{Implementation of the death penalty in the Moroccan law}

The King Mohammed VI has not signed an execution decree since he took the throne on 23 July 1999. Since then, many people on death row had their sentences commuted to life imprisonment, a further sign towards the abolition of capital punishment in the country.

On 22 May 2012, Morocco was reviewed under the Universal Periodic Review of the UN Human Rights Council. The Government reiterated that no capital punishment had been carried out since 1993, adding that there was also a draft law which aimed at reducing the number of crimes punished with death. Morocco rejected recommendations to introduce a de jure moratorium on the executions as rapidly as possible, to commute all death sentences to prison sentences and abolish, once and for all, the death penalty. However, it accepted recommendations to continue the implementation of a de facto moratorium on executions and make efforts to achieve the total abolishment of capital punishment.

On 20 December 2012, Morocco abstained from the Resolution on a Moratorium on the use of the Death Penalty at the UN General Assembly.

According to government information, 10 death sentences were imposed in Morocco in 2013, reported Amnesty International.

As of 31 March 2014, there were 117 people on death row, reported Penal Reform International (PRI).

The Moroccan legislator dedicated special provisions to the execution of the death penalty. These provisions are found in the Penal Procedure Law and the implementing decree of the law regulating the penitentiary institutions. Generally, we can classify them into two phases:

\section{Pre-execution phase}

Given the seriousness of the death penalty, the public prosecutor is obliged, by law, to inform the minister of justice, in his capacity as the one who is responsible for the penal policy, of any ruling on the death penalty once rendered, because it is about a group of convicts who are subject to special rules specified by the implementing decree of the law regulating the penitentiary institutions. The prisoners under the death penalty can be transferred immediately after pronouncing the ruling to other prisons where there is a wing for this group of prisoners. Also, they are subject to solitary confinement as far as possible. They shall be given special attention making it possible to explore their personality, follow up their psychological status and maintain their equilibrium to avoid any attempt of prison break, suicide or offence against a third party. Prisoners under the death penalty are allowed to do 
some works after consultation of a doctor and a social assistant. Also, they are allowed to receive their relatives and contact their lawyers freely in a hall meant for this purpose.

The Public Prosecutions must be predisposed automatically for pardon without means to seek public prosecutor to accept the request for amnesty, because the goal of the application is to display the punishment for the Amnesty Commission to take the decision of the King of the country, even if not requested by the convict or his family.

The King receives an advisory opinion prepared by the clemency committee (commission des grâces). The clemency committee is composed of the Minister of Justice, the head of the royal office, the Chief Justice of the Supreme Court, the chief prosecutor, the director for criminal matters and clemency, and the director of prisons.

The law stipulates that Calls on the public prosecutor and the convict lawyer to the filing of the Memorial to strengthen the application of the amnesty. The sentence cannot be executed until after refusing to seek pardon, and the answer can be reported to the lawyer of the convict only. In my opinion this is good point in our legislative; it respects the feeling of the convict.

Pursuant to the Constitution and to the Penal Code, the prerogative of clemency is exercised by the King.

\section{Post-execution phase}

The Moroccan legislator makes the execution dependant on the decision of rejecting the pardon request. For women who are proved pregnant, the execution should be after 40 days of childbirth. The death penalty shall be executed by bullets secretly in accordance with Chapter 19 of the Moroccan Penal Code, and upon a decision by the minister of justice through the military authority in the penitentiary institution where the convict is under arrest, unless it is decided the other way. The minister of justice may make the execution public or take place in another place.

The execution must be in the presence of the following persons statement:

1. President of the sentencing court, or a judge appointed by the first President of the Court of Appeal;

2. A member of the public prosecutor appointed by the President of the Court of Appeals prosecutor;

3. One of investigating judges or a judge of the Court of the place of execution;

4. Court clerks from Court of the place of execution;

5. Lawyer sentenced;

6. The prison manager, which is allocated for the implementation, or Prison manager where the detainee was convicted

7. The national security man mandated by the public prosecutor;

8. Prison doctor, or a doctor appointed by the Public Prosecutor's Office;

9. Imam of the Mosque;

The death penalty shall be executed according to special legal formalities, ended with drafting the minutes, a copy of which shall be hung for 24 hours on the gate of the penitentiary institution where the execution takes place or on the gate of the municipality, if the death penalty takes place outside the prison, and which is often a shooting range. Attaches on the door of the prison, which was implemented the death sentence, record shall writes obligatory 
and immediately from clerk about the execution of death penalty, and the record shall be signed by the President of the Criminal Chamber or on behalf of, and also the presence of representative of the public prosecutor and the clerk, the record shall not be Attached to more than twenty-four hours .

The law also prevents the publication of any document or any data relating to the implementation of the death penalty, according to Chapter 652 of the Code of Criminal Procedure.

According to Moroccan Penal Code, after the execution sentence, his or her family can receive corpse of the convict if requested, to arrange funeral themselves in a non-public place.

\section{CONCLUSION}

The abolition of the death penalty has evolved remarkably. A group of countries have abolished it, and even the ones which have not abolished it have imposed it only for the most serious crimes or its sentences but without execution. That means it is a rigid provision, as we saw it in Moroccan Law.

This paper discussed Safeguards guaranteeing protection of the rights of those facing the death penalty, unfortunately we saw that a group of countries signed the conventions but they didn't respect them. Some of violated articles are:"shall not be the death sentence for persons below 18 years of age at the time of the commission of the crime, or Capital punishment may be imposed only when the guilt of the person charged is based upon clear evidence.

In my opinion the death penalty is necessary to ensure security in the society, especially when there is an increase in the number of crimes. But more attention must be paid to safeguards guaranteeing protection of the rights of those facing the death penalty, and preventing death sentence to innocent people.

We can also build special court for most serious crimes with competent judges and familiar with a good knowledge of the criminology. Additionally, we can bring some psychology doctors to follow the convict and find out the reason for committing these types of crimes.

The reason behind the death penalty is community deterrence, without forgetting that the role of community is to know the reason behind committing the crimes, and that these crimes must be addressed legally and socially. Finally, I think the right to appeal to a court of higher jurisdiction one time is not enough, it needs to be at least twice in different categories of courts plus the right to pardon or commutation of sentence, to avoid the risk of error. 